\title{
The Effect of Music Therapy for Patients With Huntington's Disease: A Systematic Literature Review ${ }^{*}$
}

\author{
Monique van Bruggen - Rufi \\ ArtEZConservatory School of Music, Enschede, The Netherlands \\ Leiden University Medical Center, Leiden, The Netherlands \\ Atlant Care Group, Apeldoorn, The Netherlands \\ Raymund Roos \\ Leiden University Medical Center, Leiden, The Netherlands
}

\begin{abstract}
Huntington's disease is a progressive, neurodegenerative, and autosomal dominant disease characterized by motorand psychiatric disturbances, and cognitive decline. Since there is no cure, all treatment is aimed at improving quality of life. One form of non-drug therapy which is barely recognized, is music therapy. The literature on its use and effect in patients with Huntington's disease is limited. We therefore performed a detailed literature survey in order to delineate the different types of music therapy interventions and their aims. Music therapy studies were included when targeting: (1) motor disturbances; (2) cognitive disturbances; (3) psychiatric disturbances; and (4) emotional/social disturbances. A total of eight studies that met these criteria were analyzed. We found that music therapy interventions vary throughout the different stages of the disease and are not yet applied optimally. Not the stage of the disease but the individual treatment goals seem to be more determinative for the music therapy indications. In conclusion, precise aims and methods in relation to the stage of the disease are not well determined. There is a need for systematic study of this treatment option.
\end{abstract}

Keywords: music, music therapy, Huntington's disease, quality of life

\section{Introduction}

Huntington's disease (HD) is a rare neurodegenerative disorder of the central nervous system. It is a progressive, autosomal dominant disease, characterized by a triad of symptoms and signs, consisting of: (1) motor disturbances: chorea and hypokinesia; (2) cognitive decline; and (3) psychiatric disturbances: depression and behavioral changes (Roos, 2010). The prevalence of HD ranges from $1: 143$ in Venezuela to $1: 10,000,000$ in the black population of South Africa. In the Caucasian population the prevalence is estimated to be between 5 and 10 per 100,000 (Al-Jader, Harper, Krawczak, \& Palmer, 2001).

Monique van Bruggen - Rufi, MMth, NMT-F, Neurological Music Therapist Fellow, lecturer, ArtEZConservatory School of Music; Leiden University Medical Center; Atlant Care Group.

Raymund Roos, Ph.D., MD, Neurologist, Leiden University Medical Center.

Correspondence concerning this article should be addressed to Monique van Bruggen - Rufi. E-mail: m.vanbruggen-rufi@artez.nl. 
The disease can be roughly divided into three stages: the early, the middle, and the late stage. As the disease progresses, the dependability of the patient increases. Admission to a long care facility is unavoidable in most cases.

To date, there is no drug to cure or delay the onset of the disease. The majority of drugs are prescribed to treat the motor and psychiatric signs. Besides medication, many other non-drug interventions are available such as physiotherapy, occupational therapy, speech therapy, dietician advice, psychological support, social worker help, and music therapy. All treatment must be individually tailored, as the symptoms and signs are different for each person and change over time. The intention of all forms of treatment is to improve quality of life (Roos, 2010).

The term Quality of life (QoL) reflects the overall status of a combination of factors: a person's health, symptoms, and level of physical and social functioning. Functional and cognitive impairment are significantly correlated with the patient’s QoL (EHDN website ${ }^{1}$; Ready, Mathews, Leserman \& Paulsen, 2008). Health-related Quality of Life (HrQoL) is defined as follows:

"The optimum levels of physical role and social functioning, including relationships and perceptions of health, fitness, life satisfaction and well-being” (Bowling, 1995). Ho, Gilbert, Mason, Goodman, and Barker (2009) conclude that depressive mood and functional ability are critically linked to health-related QoL in HD. In a previous study, Helder, Kaptein, Kempen van, Houwelingen van, and Roos (2001) conclude that physical and psychosocial symptoms have a great impact on the patient's well-being.

Recently, the European Huntington's Disease Network (EHDN) Quality of Life Working Group initiated a qualitative research study on the impact of HD across the entire disease spectrum (Ho \& Hocaoglu, 2011). The outcome provides important implications for the management and development of interventions throughout all stages. The physical/functional theme peaked throughout the different stages, indicating that these issues were raised more frequently over the course of the disease. There were no significant changes between stages for the emotional and social themes. The cognitive impairments only featured in the early and middle stages. In the advanced late stage, the cognitive theme hardly featured any more, probably due to the degree of cognitive impairment which affects insight at this stage (Ho \& Hocaoglu, 2011). Also, in the late stages, the physical impairments become more and more evident which makes determination of the cognitive, emotional and social themes extremely difficult.

In the attempt to meet the needs of the individual, the challenge is to find adequate responses and to develop relevant and effective therapeutic strategies (Gilbertson, 2005; Aldridge, 2005). One form of non-drug therapy which is barely recognized, is music therapy. Music therapy recognizes individual needs and can be adapted to meet them. Over the past decades, music therapy is developed for patients with neurodegenerative diseases, recognizing the individual needs of the patients (Cohen-Mansfield, 2000).

\section{What is Music Therapy?}

The American Music Therapy Association (AMTA)² defines music therapy as follows:

\footnotetext{
1 European Huntington's Disease Network (EHDN), working group Quality of Life. Retrieved from http://www.euro-hd.net/html/network/groups/qual. Last accessed December 23rd, 2013.

2 American Music Therapy Association [homepage on the Internet. Retrieved from: http://www.musictherapy.org. Last accessed December 23rd, 2013].
} 
"Music therapy is the clinical and evidence-based use of music interventions to accomplish individualized goals within a therapeutic relationship by a credentialed professional who has completed an approved music therapy program”. Music therapists assess emotional well-being, physical health, social functioning, communication abilities, and cognitive skills through musical responses. Music therapists design music sessions for individuals and groups based on client needs using music improvisation, receptive music listening, song writing, lyric discussion, music and imagery, music performance, and learning through music. Finally, they are part of the multidisciplinary team and thus participate in interdisciplinary treatment planning, ongoing evaluation, and follow-up (AMA website).

\section{History of Music Therapy}

The first use of music in relation to illness can be traced back to ancient Egypt. More systematic studies on the effects of music on physiological processes such as cardiac output, respiration, pulse rate, and blood pressure were first carried out at end of the 19th century. Nowadays music is provided for relaxation purposes and pain relief (Bradt \& Dileo, 2009).

The 20th century discipline began after the First World War when musicians went to Veteran hospitals around the country to play for the thousands of veterans suffering from physical and emotional traumas. It was soon evident that the hospital musicians required some prior training before entering the facility and so the first music therapy degree programme was initiated in 1943 in the United States. In 1998, the American Music Therapy Association (AMTA) united the National Association for Music Therapy (founded in 1950) and the American Association for Music Therapy (founded in 1971) (AMTA website).

During the last decades, new MRI techniques have made it possible to visualize the brain while playing or listening to music (Peretz \& Zatorre, 2009). Studies have revealed that each musical parameter (e.g., rhythm, melody, harmony, pitch) seems to engage a broad network of brain regions (Patel, 2008). Processing the musical structure appears to trigger networks in the prefrontal and the interior frontal cortex, superior temporal poles and the cerebellum. When the music is emotionally meaningful to the listener, activity extends to the ventral tegmental area, the accumbens nucleus, and the hypothalamus (Levitin, 2009).

It has been revealed that music and motor control share specific neural circuits. This has led to the assumption that music could improve movement problems in patients with Parkinson's disease and Huntington's disease (Thaut \& McIntosh, 2010). Also, music has been shown to activate distinct neural pathways in the brain associated with emotion, such as the insula and cingulate cortex, hypothalamus, hippocampus, amygdala, and prefrontal cortex (Juslin \& Sloboda, 2010). It has, therefore, been suggested that many more patients with dementia and other age-related conditions, developmental and learning disabilities, substance abuse problems, brain injuries, physical disabilities, and acute and chronic pain, could benefit from this treatment (Magee \& Davidson, 2008; Schmid \& Aldridge, 2004; Thaut, 2005).

There is evidence that rhythmic auditory stimulation improves gait in patients with Parkinson's Disease (PD) (Thaut et al., 1996). Pacchetti et al. (2000) showed in a randomized controlled, single-blinded study beneficial effects of music therapy on affective and behavioral functions in PD patients.

Based on the insights mentioned above one can assume that music therapy could be a suitable non-drug intervention for HD. We, therefore, reviewed the literature to find out the different techniques, the primary 
outcome measures, and assessments used in music therapy in HD.

\section{Methodology}

A systematic literature search was conducted for any related publication, published between 1950, in the following databases: Medline/PubMed; Embase, Cinahl, PsychINFO/PsycIndex, and Web of Science. The following terms were included: music, music therapy, in combination with the terms Huntington and Huntington's disease.

Furthermore, (hand)searches were carried out in specific music (therapy) databases, such as:

- CAIRSS (Computer-Assisted Information Retrieval Service System), a bibliographic database of music research literature, including national and international Music Therapy journals;

- The Center for Biomedical Research in Music (CBRM);

- The digital database of the Music Therapy Neurology Network (MTNN);

- The Nordoff Robins Music Therapy Research Program.

Also, specific music therapy journals were (hand)searched including the Journal of Music Therapy and Music Therapy Perspectives, as well as reviewing reference lists of the relevant publications. Finally, conference proceedings and dissertation abstracts were reviewed.

The following inclusion criteria were used:

- Participants had to be formally diagnosed as having Huntington's disease;

- Music therapy had to be involved, targeting any of the following symptoms and signs that play a role in the quality of life of patients suffering from HD: (1) motor disturbances; (2) cognitive disturbances; (3) psychiatric disturbances; and (4) emotional/social disturbances.

The references used in this article were purposefully limited to publications that focused specifically on music therapy. All music therapy references in relation to Huntington's disease were retrieved and reviewed (see Figure 1).

The literature contains many case reports suggesting that music therapy may have an effect on the function of people with neurodegenerative diseases. The majority of these articles describe the development of music therapy practice illustrated by single case studies, clinical reports, and descriptions of methodology. The reported benefits of music therapy for neurodegenerative diseases in general are summarized in Table 1 (Aldridge, 2005).

When searching for the (MeSH)terms "Huntington’s Disease, Music and Music Therapy” we found a total of 51 references. After omitting the duplicates and the articles not fulfilling the inclusion criteria, eight articles remained: six practice based studies, two quantitative studies and two qualitative studies. Articles were screened on research design (see Table 2).

The music therapy goals and interventions described in the reviewed articles were categorized according to the targeted symptoms and signs that play a part in the quality of life op patients suffering from HD, i.e., physical (motor) $(n=5)$, cognitive $(n=3)$, psychiatric goals $(n=1)$, and social/emotional goals $(n=5)$ (see Table 3). 


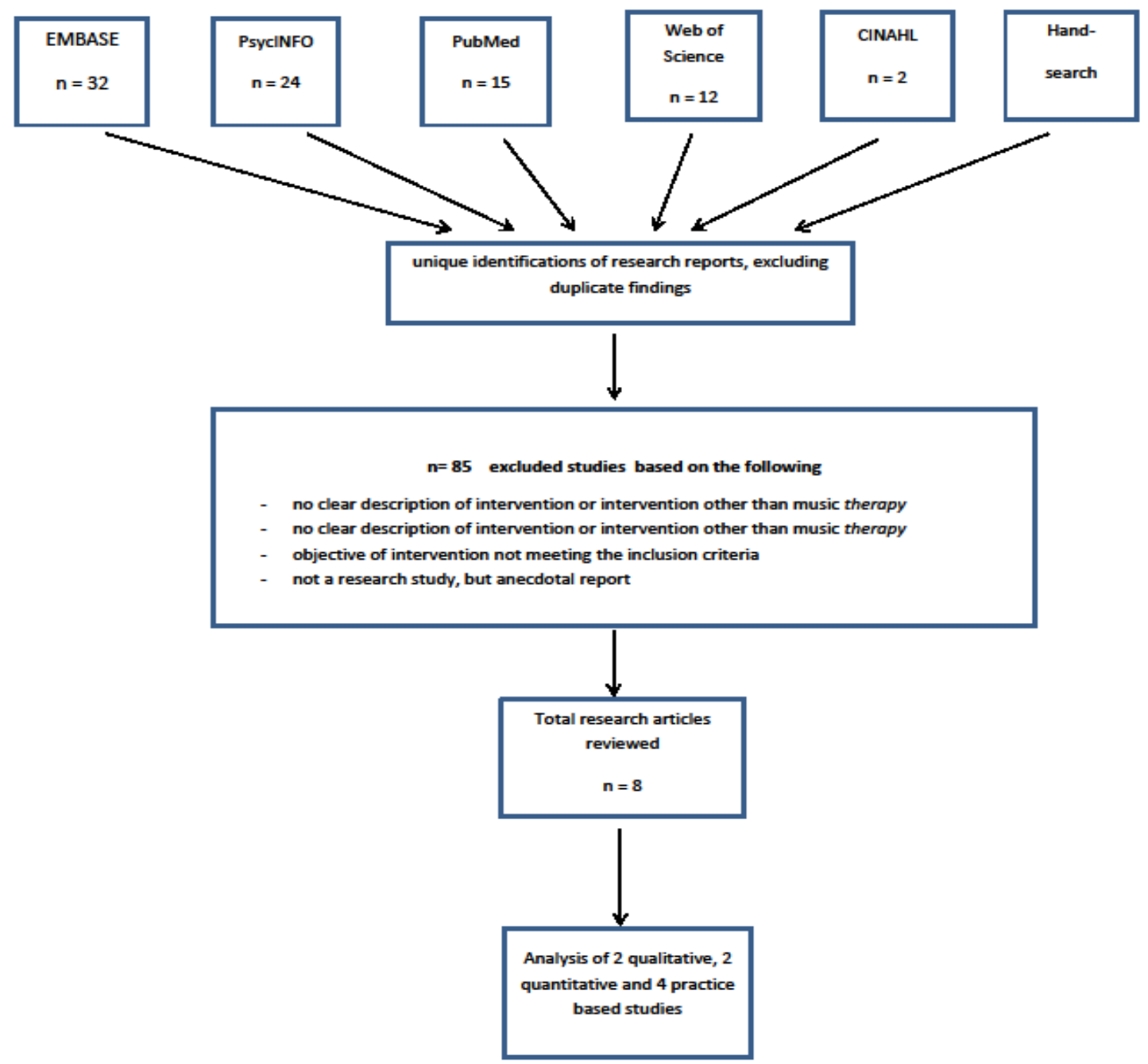

Figure 1. Flow chart search string (Last search May 13th, 2014).

\section{Results}

Table 1

Benefits of Music Therapy for the Neurodegenerative Diseases

Meets the needs of individual patients and their characteristics

Promotes dialogue and the maintenance of an identity that has a broad repertoire of possibilities

Reintegrates the person within a communicative ecology and prevents isolation

Offers a flexible temporal structure for processing temporal information where timing can be temporarily recovered and practiced

Utilizes gestural abilities, including utterance, binding events together that are indicative of ability

Gestures seen as attempts to regain cognition, not seen as failed abilities

Encourages rhythmical movement

Regulates emotional arousal in terms of expression and inhibition with implications for sufferers and caregivers

Needs can be expressed

Motivates communication and participation without being speech dependent

Attention, arousal, affect and action embodied in musical form

Note. Source: Aldridge, 2005. 
Table 2

Practice Based and Quantitative Studies, Screened on Design

\begin{tabular}{|c|c|c|c|c|c|c|}
\hline $\begin{array}{l}\text { Author and year of } \\
\text { publication }\end{array}$ & Design & Setting & $\begin{array}{l}\text { Participants } \\
\text { and } \\
\text { HD-stage }\end{array}$ & Goals & Outcome measure & Outcome results \\
\hline $\begin{array}{l}\text { Erdonmez-Grocke, } \\
1976\end{array}$ & \begin{tabular}{|l|} 
Clinical \\
observational \\
trial with \\
control group \\
\end{tabular} & \begin{tabular}{|l} 
Clinical \\
setting, \\
individual \\
treatment \\
\end{tabular} & $\begin{array}{l}N=2 \\
\text { mid-stage } \\
N=5 \text { late } \\
\text { stage }\end{array}$ & $\begin{array}{l}\text { Stimulation of } \\
\text { expressive speech }\end{array}$ & $\begin{array}{l}\text { Rating of } 3 \text { tests } \\
\text { (pre-mid-post) } \\
\text { through discussion } \\
\text { tapes }\end{array}$ & $\begin{array}{l}\text { No statistical } \\
\text { evidence for } \\
\text { improvement of } \\
\text { expressive speech }\end{array}$ \\
\hline Hoskyns, 1982 & $\begin{array}{l}\text { Observational } \\
\text { trial }\end{array}$ & $\begin{array}{l}\text { Holiday } \\
\text { Care } \\
\text { facility, } \\
\text { group } \\
\text { treatment }\end{array}$ & $\begin{array}{l}N \text { varied per } \\
\text { session, stage } \\
\text { of participant } \\
\text { varied per } \\
\text { session }\end{array}$ & $\begin{array}{l}\text { Counteract anxiety and } \\
\text { frustration, group } \\
\text { participation, } \\
\text { encouraging relaxation, } \\
\text { reducing choreic } \\
\text { movement }\end{array}$ & & $\begin{array}{l}\text { Playing instruments } \\
\text { increases choreic } \\
\text { movement. Listening } \\
\text { to music aids } \\
\text { relaxation. Short term } \\
\text { positive change in } \\
\text { behavior } \\
\end{array}$ \\
\hline Rainey Perry, 1983 & $\begin{array}{l}\text { Observational } \\
\text { trial }\end{array}$ & $\begin{array}{l}\text { Clinical } \\
\text { setting, } \\
\text { group } \\
\text { treatment }\end{array}$ & $\begin{array}{l}N=6-8, \\
\text { middle to late } \\
\text { stage }\end{array}$ & \begin{tabular}{|l|} 
Increase/maintain \\
participation, \\
attention,awaress, \\
interaction, providing \\
opportunities for \\
self-expression \\
Increase relaxation, \\
communication \\
Encourage participation \\
\end{tabular} & & $\begin{array}{l}\text { Improvement of } \\
\text { participation, } \\
\text { communication, } \\
\text { concentration, } \\
\text { memory, relaxation, } \\
\text { movement, } \\
\text { self-esteem, } \\
\text { self-expression and } \\
\text { social interaction } \\
\end{array}$ \\
\hline \multirow[t]{3}{*}{ Magee, 1995} & \begin{tabular}{|l} 
Single case \\
study, needs \\
based \\
perspective \\
\end{tabular} & $\begin{array}{l}\text { Day care } \\
\text { facility, } \\
\text { individual } \\
\text { treatment }\end{array}$ & $\begin{array}{l}N=1 \text { early } \\
\text { stage }\end{array}$ & $\begin{array}{l}\text { Providing emotional } \\
\text { outlet and means of } \\
\text { expression }\end{array}$ & & $\begin{array}{l}\text { Active participation } \\
\text { in individual music } \\
\text { therapy is } \\
\text { recommended }\end{array}$ \\
\hline & & $\begin{array}{l}\text { Clinical } \\
\text { setting, } \\
\text { group } \\
\text { treatment }\end{array}$ & $\begin{array}{l}N=1 \\
\text { mid-stage }\end{array}$ & \begin{tabular}{|l|} 
Choice making, \\
improving attention, \\
concentration, \\
encouraging \\
verbalization, stimulate \\
participation, improving \\
social skills, avoiding \\
isolation
\end{tabular} & & $\begin{array}{l}\text { Group treatment is } \\
\text { recommended, both } \\
\text { active and receptive } \\
\text { music therapy }\end{array}$ \\
\hline & & \begin{tabular}{|l|} 
Clinical \\
setting, \\
group \\
treatment \\
\end{tabular} & $\begin{array}{l}N=1 \text { late } \\
\text { stage }\end{array}$ & $\begin{array}{l}\text { Maintaining attention, } \\
\text { making decisions, } \\
\text { expression, } \\
\text { identity }\end{array}$ & & $\begin{array}{l}\text { Receptive music } \\
\text { therapy in group } \\
\text { setting is } \\
\text { recommended }\end{array}$ \\
\hline Thaut et al., 1999 & Clinical trial & $\begin{array}{l}\text { Individual } \\
\text { sessions }\end{array}$ & $\begin{array}{l}N=27 \text { all } \\
\text { stages }\end{array}$ & $\begin{array}{l}\text { Velocity modulation } \\
\text { and rhythmic } \\
\text { synchronization of gait }\end{array}$ & $\begin{array}{l}\text { Baseline setting, } \\
\text { pre- and post-test } \\
\text { of gait. Statistical } \\
\text { analysis } \\
\text { (ANOVA) }\end{array}$ & $\begin{array}{l}\text { Gait speed changed } \\
\text { using RAS, however } \\
\text { synchronization } \\
\text { negatively impacted } \\
\text { in early stage } \\
\end{array}$ \\
\hline Brandt, 2000 & $\begin{array}{l}\text { Practice based } \\
\text { clinical } \\
\text { observational } \\
\text { trial }\end{array}$ & $\begin{array}{l}\text { Clinical } \\
\text { setting, } \\
\text { individual } \\
\text { treatment }\end{array}$ & $\begin{array}{l}\text { HD mid- and } \\
\text { advanced } \\
\text { stage, } N=6\end{array}$ & $\begin{array}{l}\text { Reducing unwanted } \\
\text { movements/ } \\
\text { stimulating voluntary } \\
\text { (wanted) movements }\end{array}$ & $\begin{array}{l}\text { Rating videotapes } \\
\text { of } 1 \text { session by } 2 \\
\text { raters }\end{array}$ & $\begin{array}{l}\text { No significant } \\
\text { evidence for reducing } \\
\text { unwanted } \\
\text { movements while } \\
\text { listening to favorite } \\
\text { song }\end{array}$ \\
\hline $\begin{array}{l}\text { Davis \& Magee, } \\
2001\end{array}$ & $\begin{array}{l}\text { Practice based } \\
\text { single case } \\
\text { study }\end{array}$ & & $\begin{array}{l}\mathrm{HD} \\
N=1\end{array}$ & $\begin{array}{l}\text { Stimulating interaction } \\
\text { and } \\
\text { communication, } \\
\text { organizing responses }\end{array}$ & & $\begin{array}{l}\text { Music can offer } \\
\text { opportunities for } \\
\text { interaction and } \\
\text { communication }\end{array}$ \\
\hline
\end{tabular}


Table 3

Music Therapy and HD: Referrals and Goals

\begin{tabular}{|l|l|l|}
\hline Physical (motor) & Cognitive (dementia) & $\begin{array}{l}\text { Psychiatric (behavior) } \\
\text { And psychosocial (emotional) }\end{array}$ \\
\hline $\begin{array}{l}\text { Encourage relaxation and } \\
\text { reduction in choreic } \\
\text { movement (Hoskyns, 1982) }\end{array}$ & $\begin{array}{l}\text { Encourage group participation } \\
\text { (Hoskyns, 1982) }\end{array}$ & $\begin{array}{l}\text { Counteract anxiety and } \\
\text { frustration (Hoskyns, 1982) }\end{array}$ \\
\hline $\begin{array}{l}\text { Increase/maintain movement, } \\
\text { increase relaxation, } \\
\text { (Rainey Perry, 1983) }\end{array}$ & $\begin{array}{l}\text { Providing opportunities for } \\
\text { self-expression, encouraging participation } \\
\text { (Rainey Perry, 1983) }\end{array}$ & $\begin{array}{l}\text { Stimulating communication } \\
\text { (Rainey Perry, 1983) }\end{array}$ \\
\hline $\begin{array}{l}\text { Preservation of vocal } \\
\text { abilities, demonstrate and } \\
\text { maintaining physical strength } \\
\text { (Magee, 1995a, 1995b) }\end{array}$ & $\begin{array}{l}\text { Improvement of memory } \\
\text { function, organizing } \\
\text { information, musical } \\
\text { interaction, initiation (Magee, 1995a, 1995b) }\end{array}$ & $\begin{array}{l}\text { Stimulating active participation, } \\
\text { avoiding isolation } \\
\text { (Magee, 1995a, 1995b) }\end{array}$ \\
\hline $\begin{array}{l}\text { Gait improvement } \\
\text { (Thaut et al., 1999) }\end{array}$ & $\begin{array}{l}\text { ecall of information } \\
\text { espite memory function } \\
\text { terioration (Magee, 1995a, 1995b) }\end{array}$ & $\begin{array}{l}\text { Developing relationship, } \\
\text { increasing communicative } \\
\text { contact (Davis \& Magee, 2001) }\end{array}$ \\
\hline $\begin{array}{l}\text { Modulating velocity } \\
\text { (Thaut et al., 1999) }\end{array}$ & $\begin{array}{l}\text { Stimulating expressive speech } \\
\text { (Grocke-Erdonmez, 1976) }\end{array}$ \\
\hline $\begin{array}{l}\text { Reducing involuntary } \\
\text { movements/stimulating } \\
\text { voluntary movements } \\
\text { (Brandt, 2000) }\end{array}$ & $\begin{array}{l}\text { Increasing/organizing } \\
\text { responses (Magee, 1995a, 1995b) }\end{array}$ & $\begin{array}{l}\text { Preserving expressive } \\
\text { and communication skills } \\
\text { (Daveson, 2007) }\end{array}$ \\
\hline $\begin{array}{l}\text { Improvement of physical } \\
\text { presentation (Daveson, 2007) }\end{array}$ & $\begin{array}{l}\text { Improving cognitive skills } \\
\text { (Davis \& Magee, 2007) }\end{array}$ & $\begin{array}{l}\text { Enabling emotional } \\
\text { expression (Daveson, 2007) }\end{array}$ \\
\hline & $\begin{array}{l}\text { Improving behavior problems } \\
\text { (Daveson, 2007) }\end{array}$ \\
\hline
\end{tabular}

\section{Practice Based Studies}

Hoskyns (1982) focused on the effects of music therapy on counteracting anxiety and frustration by encouraging relaxation and group participation, and on reducing choreic movement by use of singing, playing, and listening. The most significant findings were that group singing seemed to be very beneficial and that playing musical instruments increased the choreic movement. Observation indicated a positive change in behavior of the participants, but little long term effect. Observation also suggested that listening to music aids in relaxation.

Rainey Perry (1983) conducted another relevant study in 1983. Over a period of eight month she offered music therapy sessions to small groups (six to eight participants). She developed three types of sessions: (1) music and movement; (2) music and communication/relaxation; and (3) sing along. She found that small music therapy groups helped maintain and improve functioning in the following areas: participation, communication (both verbal and nonverbal), concentration, memory, relaxation, movement, self-esteem, self-expression, and social interaction.

Magee (1995a, 1995b) focused on different stages of HD and how different music therapy interventions could be shaped to meet the changing needs throughout disease progression. She states that in the early stage the need for active participation in music therapy is desirable, preferably individual sessions. In the mid-stage group, participation is recommended, firstly because participating in a group gives the patient more time to react (and thus less confrontation with his decline), secondly because the other patients in the group can be used as a model for other group members. Finally, in the late stage the use of receptive methods is recommended in group-settings. Active playing of an instrument for as long as possible is encouraged. 
Brandt (2000) investigated the effect of performing a favorite song on the involuntary movements of $6 \mathrm{HD}$ patients in the mid- and late stage. She concluded that there was no significant difference in effect between singing the favorite song and having a conversation with the client.

Davis and Magee (2001) explored the use of a particular music therapy intervention. They describe a study about the use of structure within musical (active) improvisations with an HD-client. The main goal is to improve the expressive responses and to support interaction by increasing communicative contact through musical parameters.

\section{Quantitative Studies}

Grocke-Erdonmez (1976) conducted the first study into HD and music therapy in 7 HD patients. She focused on the stimulation of expressive speech through melodic speech therapy. She did find that several patients were able to sing out words that they had previously had trouble articulation through speech.

Thaut, Miltner, Lange, Hurt, and Hoemberg (1999) investigated the rhythmic synchronization ability of 27 HD patients under different conditions and circumstances using the Rhythmic Auditory Stimulation (RAS) techniques. The gait speed of most of the patients could be changed in the direction of the RAS cue. Synchronization of the steps was more difficult for patients in the early stage of the disease. Thaut et al. (1999) concludes that the ability to process auditive stimuli decreases as the disease progresses, due to deterioration of the cognitive abilities.

\section{Qualitative Studies}

In two qualitative studies the indication for music therapy is discussed and categorized according to the targeted symptoms and signs that play a part in the quality of life of patients suffering from Huntington's disease. The first study conducted by Daveson (2007) details the findings of an audit of music therapy referrals in a specialist in-patient setting for 16 patients with advanced Huntington's disease. These findings indicated that patients were most likely to be referred due to a need for emotional expression ( $n=10 ; 29 \%)$, maintenance of communication skills and social relationships $(n=9 ; 26)$. Furthermore, $14 \%$ of the referrals were due to occupation $(n=5), 11 \%$ to physical presentation $(n=4), 11 \%$ to behavior $(n=4)$. Cognitive factors were seldom a reason for referral $(n=3 ; 9 \%)$.

The second study (Bruggen van-Rufi, 2010) details the findings of a qualitative study, among different members of the multidisciplinary team $(n=14)$ in a nursing home specializing in HD in The Netherlands. As in the study by Daveson (2007), the aim of the study was to investigate the music therapy indications in this setting and compare the findings with the referrals in four other specialized care HD units in The Netherlands.

In this study, emotion, communication, and self-expression are most often mentioned as treatment goals for music therapists. Goals in cognitive and physical areas are less recognized. Multidisciplinary collaboration is well established in most of the clinics.

\section{Discussion}

In this study we reviewed the literature describing the effect of music therapy on improvement of the quality of life of Huntingtons disease patients. In doing so we specifically aimed at the effect of music therapy to 
influence (1) motor disturbances; (2) cognitive disturbances; (3) psychiatric disturbances; and (4) emotional/social disturbances. Further we studied the different music therapy techniques used, the primary outcome measures and assessments used in music therapy with people suffering from Huntington's disease. Subsequently we tried to discover a relation between these issues and the indication for music therapy, the stage of the disease, and the quality of life.

There seems to be a discrepancy between the indication for music therapy and the Quality of Life issues mentioned by the clients themselves (Ho \& Hocaoglu, 2011). On the one hand, conclusions are drawn stating that psychosocial and emotional issues are most often mentioned as being indications for music therapy (Daveson, 2007), while on the other hand, physical and functional problems seem to peak throughout the different stages (Ho \& Hocaoglu, 2011). In a later study, the focus was on the role of music in assisting patients to organize their responses. This indication is recognized and supported by the rationale of Davis and Magee (2001). Improvement of motor features during the musical intervention was, however, beyond the scope of their study.

There seems to be no significant change in treatment goals between the different stages as far as the emotional and social themes are concerned, whereas Magee (1995a, 1995b) emphasizes that different goals should be met throughout the different stages. However, Magee bases her conclusions on observational studies in only one patient. Not the stage of the disease but the individual treatment goals seem to be more determinative for the music therapy indications. However, a relation between these two issues is plausible. Thaut et al. (1999) state that certain goals can no longer be met, most probably because of the decline of cognitive abilities throughout the different stages. This is more obvious when patients are given different instructions. Delval et al. (2009) confirm the difficulties with multi-tasking in people with HD, due to attention deficit.

The sample size of Brandt (2000) was too small $(n=6)$ and the study consisted of only one music therapy session, so no useful conclusions could be drawn. Furthermore, the type of music as well as the manner in which it is offered in the different interventions raises questions (Magee, 1995b; Brandt, 2000): Would different music styles, different instruments, different approaches have made the difference? Unfortunately there are no comparative studies of how these factors influence meeting the treatment goals.

The outcome of the two qualitative studies mentioned above confirms the lack of referrals to music therapy due to a cognitive need. Obviously, in contrast with Alzheimer's disease where cognitive decline is the primary outcome measure, this is is not an indication for music therapy in Huntington's disease. These findings can be supported by Leng et al. (2003) who identified that therapeutic intervention cannot assist with regaining cognitive abilities throughout HD progression.

The findings of the two qualitative studies (Daveson, 2007; Bruggen van-Rufi, 2010) are in line with the role that has been highlighted within the practice literature: Music therapy can be used to provide a means of self-expression, social interaction, and communication.

\section{Conclusion and Recommendation}

Music therapy interventions used to improve quality of life for people with HD vary and are not applied optimally. In none of the studies that we reviewed Quality of Life was the primary outcome. In our opinion, this also has to do with the fact that there is no consensus about which items of Quality of Life matter most for HD-patients, or at which stage of the disease (Ho et al., 2009; Helder et al., 2001; Ho \& Hocaoglu, 2011). Due to 
the changing needs of the patient, the treatment itself has to be adjusted to the individual needs that are important at that specific moment. Being alert to the patient's signals demands flexibility from all members of the therapeutic team. The aim of the therapy might not be to restore or regain function, but rather to maintain function and provide opportunities for compensatory behavior to be supported, developed, and rehearsed (Thaut et al., 1999). Functional training can be combined with cognitive, emotional, and communicative/relational approaches. In so doing, the music therapist makes a link between medical and psychological treatment. Within music therapy, the medium of intervention (the music itself) does not have to be changed. In our opinion, therefore, music therapy could be a suitable non-drug intervention for improving the quality of life of those living with HD in every stage.

The majority of articles that examined different music therapy interventions to improve Quality of Life of people living with HD were derived from observational studies. However, it must be noticed that the studies were often small scaled and the number of music therapy sessions were limited. Therefore we plan a systematic study of the effect of music therapy in HD.

\section{References}

Aldridge, D. (2005). Music therapy and neurological rehabilitation: Performing health (1st ed.). London/Philadelphia: Jessica Kingsley Publishers.

Al-Jader, L. N., Harper, P. S., Krawczak, M., \& Palmer, S. R. (2001). The frequency of inherited disorders database: Prevalence of Huntington disease. Community Genetics, 4, 148-157.

Bowling, A. (1995). Measuring disease: A review of disease-specific quality of life measurement scales. Buckingham: Open University Press.

Bradt, J., \& Dileo, C. (2009). Music for stress and anxiety reduction in coronary heart disease patients. Retrieved from http://www.ncbi.nlm.nih.gov/pubmed/19370642

Brandt, M. (2000). Onderzoek muziektherapie bij ziekte van Huntington: gebruik van een gezongen lievelingslied bij het stimuleren van willekeurige responsies (Music therapy and Huntington's disease: Research of the use of a favorite song, performed live, to stimulate voluntary movements). Tijdschrift voor creatieve therapie, 3, 22-27.

Bruggen van-Rufi, M. (2010). Multi- and interdisciplinary collaboration between the music therapist and other professionals in Hungtington's patient care (Unpublished Master's Thesis Zuyd University, Heerlen, The Netherlands).

Cohen-Mansfield, J. (2000). Use of patient characteristics to determine non-pharmacologic interventions for behavioral and psychological symptoms of dementia. International Psychogeriatrics, 12(suppl. 1), 373-380.

Daveson, B. (2007). Findings of an audit of music therapy referrals in a specialist in-patient setting for 16 patients with advancing Hungtinton's disease. Australian Journal of Music Therapy, 18, 2-19.

Davis, G., \& Magee, W. (2001). Clinical improvisation within neurological disease: Exploring the effect of structured clinical improvisation on the expressive and interactive responses of a patient with Huntington's disease. British Journal of Music Therapy, 15(2), 51-60.

Delval, A., Krystkowiak, P., Delliaux, M., Blatt, J. L., Derambure, P., \& Destée, A. (2009). Effect of external cueing on gait in Huntington’s Disease. Movement Disorders, 23(10), 1446-1452.

Gilbertson, S. K. (2005). Music therapy in neurorehabilitation after traumatic brain injury: A literature review. In D. Aldridge (Ed.), Music therapy and neurological rehabilitation: Performing health (pp. 83-139) (1st ed.) London/Philadelphia: Jessica Kingsley Publishers.

Grocke-Endormez, D. (1976). The effect of music therapy in the treatment of Huntington's Chorea Patients. Proceedings of the 2nd National Conference of the Australian Music Therapy Association Incorporated Melbourne (pp. 58-64).

Helder, D. I., Kaptein, A. A., Kempen van, G. M., Houwelingen van, J. C., \& Roos, R. A. (2001). Impact of Huntington’s disease on quality of life. Movement Disorders, 16(2), 325-330.

Ho, A. K., \& Hocaoglu, M. B. (2011). Impact of Hungtinton's across the entire disease spectrum: The phases and stages of disease from the patient perspective. Clinical Genetics, 80, 235-239. 
Ho, A. K., Gilbert, A. S., Mason, S. L., Goodman, A. O., \& Barker, R. A. (2009). Health related quality of life in Huntington's disease: Which factors matter most? Movement Disorders, 24, 574-578.

Hoskyns, S. (1982). Striking the right chord. Nursing Mirror, 2, 14-17.

Juslin, P. N., \& Sloboda, J. A. (2010). Handbook of music and emotion: Theory, research, applications. Oxford: Oxford University Press.

Leng, T. R., Woodward, M. J., Stokes, M. J., Swan, A. V., Wareing, L. A., \& Baker, R. (2003). Effects of multisensory stimulation in people with Huntington's disease: A randomized controlled pilot study. Clinical Rehabilitation, 17, 30-41.

Levitin, D. J. (2009). The neural correlates of temporal structure in music. Music and Medicine, 1, 9-13.

Magee, W. (1995a). Case studies in Huntington's disease: Music therapy assessment and treatment in the early to advanced stages. British Journal of Music Therapy, 9(2), 13-19.

Magee, W. (1995b). Music therapy as part of assessment and treatment for people living with Huntington's disease. In C. Lee (Ed.), Proceedings of the International Conference Music Therapy in Palliative Care (pp. 173-183). Oxford: Sobell Publications.

Magee, W. L., \& Davidson, J. W. (2008). Music therapy in the treatment of multiple sclerosis: A systematic qualitative analysis. Clinical Rehabilitation, 22(1), 81-82.

Pacchetti, C., Mancini, F., Ablieri, R., O’Fundar, C., Martignoni, E., \& Nappi, G. (2000). Active music therapy in Parkinson’s disease: An integrative method for motor and emotional rehabilitation. Psychosomatic Medicine, 62, 386-393.

Patel, A. D. (2008). Music, language and the Brain. Oxford: Oxford University Press.

Peretz, I., \& Zatorre, R. (2009). The cognitive neuroscience of music (2nd ed.). Oxford: Oxford University Press.

Rainey Perry, M. (1983). Music therapy in the care of Huntington's disease patients. The Australian Music Therapy Association Bulletin, 6(4). 2-11.

Ready, R., Mathews, M., Leserman, A., \& Paulsen, J. S. (2008). Patient and caregiver quality of life in Huntington’s disease. Movement Disorders, 5, 721-726.

Roos, R. A. C. (2010). Huntington's disease: A clinical review. Orphanet Journal of Rare Diseases, 5, 40.

Schmid, W., \& Aldridge, D. (2004). Active music therapy in the treatment of multiple sclerosis patients: A matched control study. Journal of Music Therapy, 41(3), 225-240.

Thaut, M. H. (2005) Rhythm, music and the brain: Scientific foundations and clinical applications (1st ed.). New York: Routledge.

Thaut, M. H., \& McIntosch, G. C. (2010). How music helps to heal the injured brain: Therapeutic use crescendos thanks to advances in brain science. Retrieved from http://www.dana.org/news/cerebrum/detail.aspx?id=26122

Thaut, M. H., McIntosh, G. C., Rice, R. R., Miller, R. A., Rathbun, J., \& Brault, J. M. (1996). Rhytmic auditory stimulation in gait training for Parkinson's disease patients. Movement Disorders, 11(2), 193-200.

Thaut, M. H., Miltner, R., Lange, H. W., Hurt, C. P., \& Hoemberg, V. (1999). Velocity modulation and rhythmic synchronization of gait in Huntington's disease. Movement Disorders, 14(5), 808-819. 